\title{
THE EXCRETION OF PREGNANEDIOL AND 17-KETOSTEROIDS DURING THE MENSTRUAL CYCLE IN BENIGN HIRSUTISM
}

\author{
BY \\ W. H. H. MERIVALE \\ From the Department of Clinical Pathology, Guy's Hospital, London \\ (RECEIVED FOR PUBLICATION JUNE 22, 1950)
}

In 1949 Koets reported a variation in the urinary 17-ketosteroid excretion occurring during the menstrual cycle of women with benign hirsutism, the maximal excretion being at, or about, the presumed time of ovulation.

It has been established that in normal women there is little or no cyclical fluctuation in the excretion of 17-ketosteroids (Werner, 1941; Patterson, McPhee, and Greenwood, 1942; Venning and Kazmin, 1946), although Furuhjelm (1948), from a careful study of 19 healthy subjects, concluded that there is a tendency for excretion to decrease during menstruation and to rise slightly during the secretory phase.

Although the condition of benign hirsutism is often accompanied by some menstrual irregularity, Koets only assumed, but did not establish, that his patients had ovulated. It seemed of some importance to define the relationship of the peak of 17-ketosteroid excretion, which he described, to events in the ovarian cycle.

Venning and Browne (1937) found that the rate of excretion of pregnanediol during the menstrual cycle could be related to the formation and regression of the corpus luteum. Furthermore, there is now no doubt that pregnanediol is one of the principal metabolites of progesterone (Buxton and Westphal, 1939; Hamblen, Cuyler, and Hirst, 1940; Venning and Browne, 1938, 1940; Heard, Bauld, and Hoffman, 1941; Sommerville and Marrian, 1950). It was decided, therefore, to estimate the 17-ketosteroid and pregnanediol concentrations of each specimen of urine collected during the menstrual cycles of a number of hirsute women. It is the purpose of this paper to report the results of these experiments.

\section{Material of the Investigation}

Twenty-four-hour specimens of urine were collected from four healthy young women, aged 22 to 29 years, with a normal menstrual history and normal distribution and quantity of body hair, and from ten patients who had been referred to the Endocrine Clinic at Guy's Hospital complaining of hirsutism, or in whom hirsutism had been noted in the course of examination for some other complaint. Urine collections were made between November and May on the seventh, 14th, 21 st and, where possible, between the 25 th and the 28 th days after the onset of the last menstrual period; the date of the collection of the last specimen was adjusted to suit 


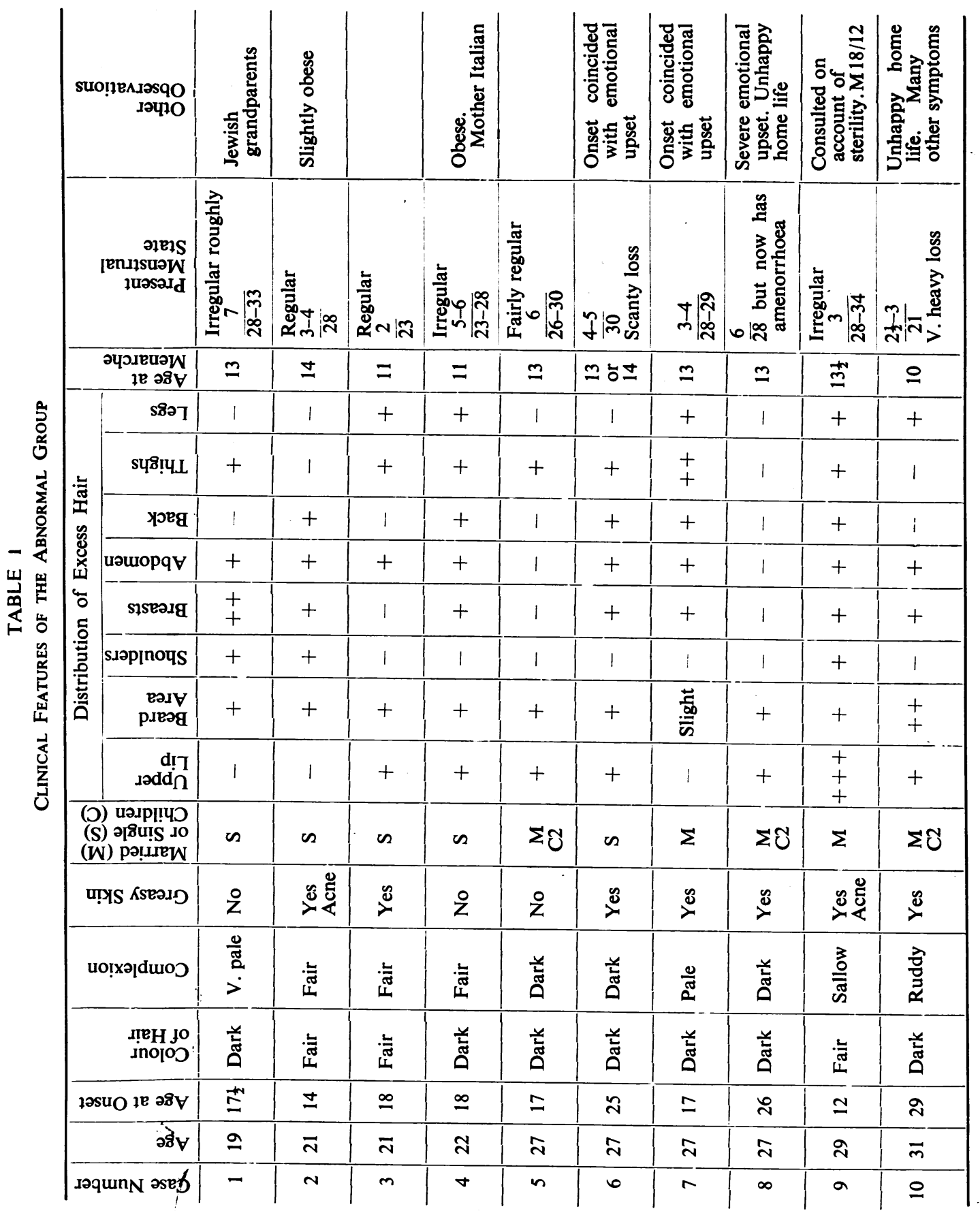


individual menstrual irregularities as required. Both the normal subjects and the patients carried on their daily work as usual during the period of the experiment.

The clinical features of the abnormal group are summarized in Table I. In no case was there a family history of hirsutism. It seems worth pointing out that the onset of the hirsutism in four cases (Nos. 6, 7, 8, and 10) dated from the occurrence of severe emotional upset and personal unhappiness.

\section{Methods}

Urine specimens were collected in bottles containing $3 \mathrm{~g}$. of a mixture of powdered thymol and salicylic acid ( $2: 1 \mathrm{w} / \mathrm{w}$ ) to prevent bacterial growth (Bisset, Brooksbank, and Haslewood, 1948). Estimations were made within 24 hours of the completion of the collection of urine wherever possible, and never more than 48 hours after the collection was finished. Where any delay occurred, specimens were stored at $2-4^{\circ} \mathrm{C}$. until they were processed.

Pregnanediol was estimated by the method of Sommerville, Gough, and Marrian (1948).

Extracts of the urine containing the neutral ketonic fraction were prepared by the method of Talbot, Butler, and MacLachlan (1940), modified only as regards the preparation of the crude neutral fraction, which was carried out as follows:

Urine, $250 \mathrm{ml}$, and sulphur-free toluene, $50 \mathrm{ml}$., were placed in a flask of $500 \mathrm{ml}$. capacity which was attached by a ground glass joint to a bulb reflux condenser. The urine was brought to the boil on an electric hot-plate and $25 \mathrm{ml}$. concentrated hydrochloric acid added down the condenser. Boiling was continued for exactly 10 minutes. The apparatus was then disconnected and the flask and contents cooled rapidly in running water.

The urine-toluene mixture was transferred to a separating funnel of $1,000 \mathrm{ml}$. capacity and shaken. Separation of the emulsion was aided by filtration through a Whatman No. 1 filter paper on a Buchner funnel using gentle suction. The urine which separated from the emulsion was added to the urine pool before each subsequent extraction. The urine was extracted twice more with $50 \mathrm{ml}$. toluene, separation of the emulsion being similarly effected.

The combined toluene extracts were washed three times with $50 \mathrm{ml} .10 \%(\mathrm{w} / \mathrm{v})$ sodium hydroxide solution, and twice with $50 \mathrm{ml}$. distilled water.

The extract was then dried with anhydrous sodium sulphate and the toluene evaporated on a boiling water bath at a pressure of $30 \mathrm{~mm}$. of mercury.

The colorimetric assay of the neutral ketonic fraction was performed by the method of Holtorff and Koch (1940), except that the dilution of the final coloured solution was made with $70 \%$ ethanol instead of $95 \%$ as used by these authors.

Creatinine was estimated by the method of Folin (1905a).

\section{Results}

Table II shows the results of estimations of pregnanediol, 17-ketosteroids, and creatinine on the urines of four healthy subjects.

The creatinine excretion was estimated in order to exclude incompleteness of urine collections. Wang (1939) and Albanese and Wangerin (1944) have shown that the creatinine excretion in any individual is not so constant as was originally assumed by Folin (1905b), and that fluctuations of the order of 10 to $25 \%$ are the rule. (Figures in parentheses in Tables II and III refer to the concentration of steroids in mg. per $\mathrm{g}$. of creatinine). This method of correcting concentrations of steroids in 24-hour urine specimens to an approximately constant volume of urine for the individual was proposed by Jayle and Libert (1946), and seems acceptable provided that there is no gross diuresis and the limitations of using the creatinine excretion as a yardstick are borne in mind. 
TABLE II

Excretion of Pregnanediol, 17-Ketosteroids, and Creatinine during Menstrual Cycles of Four Healthy WOMEn WITH Normal Hair Distribution

\begin{tabular}{c|c|c|c|c|c}
\hline $\begin{array}{c}\text { Subject } \\
\text { No.* }\end{array}$ & $\begin{array}{c}\text { Day of } \\
\text { Cycle }\end{array}$ & $\begin{array}{c}\text { Pregnanediol } \\
\text { (mg. per 24 hrs.) }\end{array}$ & $\begin{array}{c}\text { 17-Ketosteroids } \\
\text { (mg. per 24 hrs.) }\end{array}$ & $\begin{array}{c}\text { Creatinine } \\
\text { (g. per 24 } \\
\text { hrs.) }\end{array}$ & $\begin{array}{c}\text { Urine } \\
\text { Volume (ml } \\
\text { per 24 hrs.) }\end{array}$ \\
\hline 1 & 7 & $0.28(0.35) \dagger$ & $8.0(10.2)$ & 0.79 & 625 \\
& 14 & $0.44(0.35)$ & $11.2(9.0)$ & 1.25 & 980 \\
\hline 2 & 20 & $2.20(2.09)$ & $12.9(12.3)$ & 1.05 & 880 \\
\hline & 7 & $0.81(0.55)$ & $5.3(3.6)$ & 1.48 & 1650 \\
& 21 & $0.43(0.33)$ & $5.8(4.4)$ & 1.33 & 1460 \\
& 27 & $1.35(1.87)$ & $6.9(5.5)$ & 1.26 & 1580 \\
& 7 & $0.82(0.81)$ & $7.5(5.6)$ & 1.33 & 1370 \\
\hline 4 & 14 & $1.71(1.31)$ & $7.2(6.9)$ & 1.04 & 1120 \\
& 21 & $0.81(0.64)$ & $8.9(7.6)$ & 1.31 & 1550 \\
& 7 & $0.91(0.83)$ & $4.7(4.3)$ & 1.26 & 1550 \\
\hline & 21 & $0.51(0.43)$ & $8.0(6.7)$ & 1.10 & 1100 \\
& 27 & $0.53(0.52)$ & $7.5(7.3)$ & 1.20 & 1240 \\
& $0.91(0.76)$ & $6.4(5.3)$ & 1.02 & 890 \\
\hline
\end{tabular}

*Subjects 1 and 3 menstruated on the 21 st and 22nd days respectively, Subjects 2 and 4 on the 28th day.

†Denote the concentrations of steroids excreted expressed in mg. per g. creatinine.

Reference to Table II shows that Subjects 1, 2, and 3 exhibited increased luteal activity towards the end of the cycle, as shown by the rise in pregnanediol excretion to more than $1.5 \mathrm{mg}$. a day. Venning and Browne (1937) and Cope (1940) showed that the excretion of pregnanediol in the luteal phase of the menstrual cycle varied from 1 to $8 \mathrm{mg}$. of the conjugated excretory product, pregnanediol glucuronide, daily; during the follicular phase only minimal quantities are usually excreted. Case 4 failed to show any real peak of pregnanediol excretion; it is possible that her peak excretion was missed through doing the estimations at weekly intervals, but experience of doing the estimations in this way suggests that this was unlikely, and that she did not, in fact, show any increase of luteal activity and therefore did not ovulate (Venning and Browne, 1937).

The 17-ketosteroid excretion of all these subjects varied during the cycle by a maximum of $3.3 \mathrm{mg}$. (Subject 4), the greater fluctuation found in Subject 1 being almost certainly attributable to the fact that the first urine specimen was incomplete. There is a tendency in all subjects for the 17-ketosteroid excretion to increase towards the middle or end of the cycle.

Table III shows the results of estimations of pregnanediol, 17-ketosteroids, and creatinine on the urines of ten women with hirsutism.

Case 9 did not show any luteal activity, as revealed by a rise in pregnanediol excretion during her cycle. She is therefore comparable with Subject 4 of the healthy series (Table II).

Case 8, who had had amenorrhoea for 13 months before the experiment and during it, consistently excreted amounts of pregnanediol which might normally be expected 
TABLE III

Excretion of Pregnanediol, 17-Ketosteroids, and Creatinine at Intervals during the Menstrual Cycles of Ten Women with Hirsutism

\begin{tabular}{|c|c|c|c|c|c|}
\hline $\begin{array}{l}\text { Case } \\
\text { No. }\end{array}$ & $\begin{array}{l}\text { Day of } \\
\text { Cycle }\end{array}$ & $\begin{array}{l}\text { Pregnanediol } \\
\text { (mg. per } 24 \text { hrs.) }\end{array}$ & $\begin{array}{l}\text { 17-Ketosteroids } \\
\text { (mg. per } 24 \text { hrs.) }\end{array}$ & $\begin{array}{c}\text { Creatinine } \\
\text { (g. per } 24 \\
\text { hrs.) }\end{array}$ & \begin{tabular}{|c} 
Urine \\
Volume (ml. \\
per $24 \mathrm{hrs})$.
\end{tabular} \\
\hline 1 & $\begin{array}{r}7 \\
14 \\
20 \\
24 \\
32\end{array}$ & $\begin{array}{l}0.58(0.36) * \\
0.56(0.35) \\
1.16(0.68) \\
0.73(0.56) \\
2.31(2.05)\end{array}$ & $\begin{array}{c}9.8(6.13) \\
13.8(8.7) \\
13.5(7.9) \\
13.7(10.5) \\
14.6(12.9)\end{array}$ & $\begin{array}{l}1.60 \\
1.58 \\
1.70 \\
1.30 \\
1.13\end{array}$ & $\begin{array}{l}1440 \\
1450 \\
1920 \\
1125 \\
1040\end{array}$ \\
\hline 2 & $\begin{array}{r}7 \\
14 \\
21 \\
27\end{array}$ & $\begin{array}{l}3.10(1.64) \\
2.85(1.59) \\
6.65(3.80) \\
2.10(1.31)\end{array}$ & $\begin{array}{l}15.2(8.0) \\
25.8(14.3) \\
28.7(16.4) \\
18.7(11.3)\end{array}$ & $\begin{array}{l}1.89 \\
1.80 \\
1.75 \\
1.00\end{array}$ & $\begin{array}{r}1670 \\
1650 \\
1538 \\
900\end{array}$ \\
\hline 3 & $\begin{array}{r}7 \\
15 \\
21\end{array}$ & $\begin{array}{l}0.54(0.38) \\
0.94(0.99) \\
1.69(0.92)\end{array}$ & $\begin{array}{l}15.2(10.7) \\
14.4(15.2) \\
18.5(10.1)\end{array}$ & $\begin{array}{l}1.42 \\
0.94 \\
1.84\end{array}$ & $\begin{array}{r}1450 \\
700 \\
1740\end{array}$ \\
\hline 4 & $\begin{array}{r}7 \\
15 \\
22\end{array}$ & $\begin{array}{l}0.62(0.39) \\
0.93(0.67) \\
5.15(3.43)\end{array}$ & $\begin{array}{l}11.0(6.9) \\
16.5(11.8) \\
21.7(14.5)\end{array}$ & $\begin{array}{l}1.60 \\
1.40 \\
1.50\end{array}$ & $\begin{array}{l}1700 \\
1320 \\
1445\end{array}$ \\
\hline 5 & $\begin{array}{r}7 \\
14 \\
21 \\
27\end{array}$ & $\begin{array}{l}0.91(0.57) \\
0.89(0.62) \\
5.73(3.58) \\
1.33(0.84)\end{array}$ & $\begin{array}{l}12.8(8.0) \\
12.6(8.7) \\
33.0(20.6) \\
13.2(8.2)\end{array}$ & $\begin{array}{l}1.58 \\
1.45 \\
1.63 \\
1.59\end{array}$ & $\begin{array}{l}1405 \\
1070 \\
1755 \\
1410\end{array}$ \\
\hline 6 & $\begin{array}{r}7 \\
14 \\
21\end{array}$ & $\begin{array}{l}0.79(0.36) \\
2.05(0.95) \\
1.46(1.47\end{array}$ & $\begin{array}{l}13.1(5.9) \\
33.6(15.5) \\
11.9(12.1)\end{array}$ & $\begin{array}{l}2.20 \\
2.17 \\
0.99\end{array}$ & $\begin{array}{r}2365 \\
2210 \\
820\end{array}$ \\
\hline 7 & $\begin{array}{r}7 \\
14 \\
21 \\
26\end{array}$ & $\begin{array}{l}0.45(0.30) \\
0.93(0.72) \\
3.60(3.53) \\
1.90(1.26)\end{array}$ & $\begin{array}{l}14.2(9.5) \\
14.7(11.3) \\
16.1(15.8) \\
11.3(7.5)\end{array}$ & $\begin{array}{l}1.49 \\
1.30 \\
1.02 \\
1.51\end{array}$ & $\begin{array}{l}1365 \\
1250 \\
1000 \\
1450\end{array}$ \\
\hline 8 & $\begin{array}{r}7 \\
16 \\
21 \\
28\end{array}$ & $\begin{array}{l}4.12(1.82) \\
2.23(1.01) \\
2.35(1.68) \\
5.65(2.29)\end{array}$ & $\begin{array}{l}45.4(20.0) \\
46.8(22.3) \\
23.3(16.5) \\
54.2(22.0)\end{array}$ & $\begin{array}{l}2.27 \\
2.11 \\
1.40 \\
2.46\end{array}$ & $\begin{array}{l}2520 \\
2810 \\
1400 \\
2490\end{array}$ \\
\hline 9 & $\begin{array}{r}7 \\
14 \\
21 \\
27\end{array}$ & $\begin{array}{l}0.54(0.43) \\
0.14(0.10) \\
0.54(0.39) \\
0.09(0.06)\end{array}$ & $\begin{array}{l}9.9(7.7) \\
8.8(6.6) \\
6.2(4.5) \\
6.5(4.7)\end{array}$ & $\begin{array}{l}1.28 \\
1.32 \\
1.40 \\
1.38\end{array}$ & $\begin{array}{l}1460 \\
1538 \\
1730 \\
1725\end{array}$ \\
\hline 10 & $\begin{array}{r}7 \\
14 \\
21 \\
27\end{array}$ & $\begin{array}{l}1.26(0.78) \\
0.50(0.27) \\
1.88(1.14) \\
0.73(0.45)\end{array}$ & $\begin{array}{l}9.8(5.8) \\
12.5(6.8) \\
16.7(10.1) \\
14.4(9.0)\end{array}$ & $\begin{array}{l}1.62 \\
1.83 \\
1.65 \\
1.60\end{array}$ & $\begin{array}{l}2090 \\
1630 \\
1740 \\
1600\end{array}$ \\
\hline
\end{tabular}

Case 1 menstruated on the 35 th day; case 3 on the 22 nd day; case 4 on the 24 th day; case 6 on the evening of the 21 st day ; case 8 had amenorrhoea. All the other cases menstruated on the 28 th or 29 th days.

Sample 2 from case 3 is known to be incomplete. Sample 3 from case 6 consists of day urine only, since she began to menstruate at $6 \mathrm{p} . \mathrm{m}$. of the $21 \mathrm{st}$ day. Sample 3 from case 7 is known to be incomplete by about 7 hours during the day. 
during the luteal phase of the cycle. This finding was associated with a raised 17ketosteroid excretion throughout. It is possible that the colour developed by pregnanediol in the estimations may have been enhanced by the presence of abnormal amounts of 17-ketosteroids, thus giving a falsely high result (Sommerville et al., 1948). On the other hand, if the pregnanediol results are true ones, it supports the possibility that this is a case of suprarenal hyperplasia rather than benign hirsutism, since ovarian tumour was excluded at clinical examination.

It is doubtful whether Case 3 can be regarded as having shown any luteal activity. The second urine collection from this patient was almost certainly incomplete, and there is reason to believe that the third specimen was collected over a period of more than 24 hours. The results of pregnanediol estimations imply that no definite peak of excretion occurred.

The remaining cases all excreted an increased amount of pregnanediol towards the end of their cycles, the quantity varying from $1.88 \mathrm{mg}$. by Case 10 to $6.65 \mathrm{mg}$. by Case 2. Case 2 is of additional interest, since the levels of pregnanediol excretion during the follicular phase were higher than is usual.

The 17-ketosteroid excretion of these cases, in which the results of the pregnanediol estimations indicate ovulation, show a marked cyclical fluctuation. This is most pronounced in Cases 2, 4, 5, and 6, and less so in Cases 1 and 10: There is little doubt that it would have been more significant in Case 7 if the third urine collection had not been incomplete. These findings contrast with those of the normal subjects and with those of Case 9. She did not apparently ovulate, and her 17ketosteroid excretion decreased slightly throughout the month.

The peak of 17-ketosteroid excretion seems to coincide with that of pregnanediol, a fact emphasized by the results in Case 9, where no peak of pregnanediol excretion was detected, and no cyclical variation of 17-ketosteroid excretion occurred.

\section{Discussion}

These results confirm Koets's (1949) findings of a variation in 17-ketosteroid excretion occurring during the menstrual cycle of hirsute women who ovulate. However, instead of the peak 17-ketosteroid excretion occurring at the time of ovulation, as Koets asserted, the results presented here relate it closely to luteal activity and the excretion of pregnanediol. It is possible that this association may be quite fortuitous, the increased excretion of 17-ketosteroids being attributable directly to ovarian activity, since Parkes (1937) and Deanesly (1938) have produced some evidence for ovarian secretion of androgenic material, which as yet remains unidentified: or the suprarenal cortex may be stimulated to increased 17-ketosteroid production by some substance produced in the ovary or elsewhere at this time in the cycle. The latter possibility is being investigated and the results will be published later. It is enough to say that so far there is no indication of any increase of suprarenal activity with respect to the excretion of other steroids at the time when 17-ketosteroid excretion is maximal.

It may be that the substance participating in the Zimmerman reaction, and thus contributing to the colour formed by 17-ketosteroids in the urine extracts, is not itself a 17-ketosteroid but a 20 -ketosteroid such as pregnanolone, which is known to be an intermediate metabolite of progesterone. 
If the excretion of pregnanediol and of 17-ketosteroids in benign hirsutism is related, the possibility that this points to an abnormality of progesterone metabolism cannot be ignored. Marrian (1939) suggested a possible metabolic pathway for the conversion of progesterone to C19 17-ketosteroids, but it has not so far proved possible to establish by isolation studies that such a process occurs, in spite of the strong theoretical probability. It is conceivable that in the hirsute woman there is an exaggeration of normal progesterone metabolism along these lines. Preliminary observations on this aspect of the problem have been started in this Department, but it is too early to draw any definite conclusions yet.

\section{Summary}

Pregnanediol and 17-ketosteroid estimations were made at intervals during the menstrual cycles of four healthy women and ten women with hirsutism.

In contrast to the healthy group the women with hirsutism who óvulated showed a distinct cyclical fluctuation of 17-ketosteroid excretion, which was apparently related to the peak of pregnanediol excretion occurring during the luteal phase of the cycle. One hirsute woman, who did not show any peak of pregnanediol excretion, showed no increase of 17-ketosteroid excretion.

The results are discussed, and further steps in the work indicated.

I am indebted to Dr. P. M. F. Bishop for allowing me to carry out these experiments on his patients and for his advice and interest. Dr. R. M. de Mowbray kindly arranged for patients to see me.

I wish to thank Mr. D. Bawden for help with the technical work.

This work would not have been possible without the loyal and enthusiastic co-operation of the patients and healthy controls, to whom I arn very grateful.

\section{REFERENCES}

Albanese, A. A., and Wangerin, D. M. (1944). Science, 100, 58.

Bisset, N. G., Brooksbank, B. W. L., and Haslewood, G. A. D. (1948). Biochem. J., 42, 366.

Buxton, C. L., and Westphal, U. (1939). Proc. Soc. exp. Biol., N.Y., 41, 284.

Cope, C. L. (1940). Clin. Sci., 4, 217.

Deanesly, R. (1938). J. Physiol., 92,34 P.

Folin, O. (1905a). Amer. J. Physiol., 13, 45. (1905b). Ibid., 13, 66.

Furuhjelm, M. (1948). Acta endocrinol., Kbh., 1, 238.

Hamblen, E. C., Cuyler, W. K., and Hirst, D. V.(1940). Endocrinology, 27, 172.

Heard, R. D. H., Bauld., W. S., and Hoffman, M. M. (1941). J. biol. Chem., 141, 709.

Holtorff, A. F., and Koch, F. C. (1940). Ibid., 135, 377.

Jayle, M. F., and Libert, O. (1946). Bull. Soc. Chim. biol., 28, 372.

Koets, P. (1949). J. clin. Endocrinol., 9, 795.

Marrian, G. F. (1939). Harvey Lect., Ser. 34, p. 37. Baltimore.

Parkes, A. S. (1937). Nature, Lond., 139, 965.

Patterson, J., McPhee, I. M., and Greenwood, A. W. (1942). Brit. med. J., 1, 35.

Sommerville, I. F., Gough, N., and Marrian, G. F. (1948). J. Endocrinol., 5, 247.

_ and Marrian, G. F. (1950). Biochem. J., 46, 290.

Talbot, N. B., Butler, A. M., and Maclachlan, E. (1940). J. biol. Chem., 132, 595.

Venning, E. H., and Browne, J. S. L. (1937). Endocrinology, 21, 711.

- (1938). Amer. J. Physiol., 123, 209.

- (1940). Endocrinology, 28, 707.

Wang, E. (1939). Acta med. scand., Suppl., 105.

Werner, S. C. (1941). J. clin. Invest., 20, 21. 